\title{
Cover Cropping in Rainfed Fruticulture
}

\author{
M Ângelo Rodrigues*, Soraia Raimundo and Margarida Arrobas \\ Centro de Investigação de Montanha (CIMO), Portugal
}

*Corresponding author: M Ângelo Rodrigues, Centro de Investigação de Montanha (CIMO), Instituto Politécnico de Bragança, Portugal.

Received Date: December 21, 2018

Published Date: January 09, 2019

\section{Introduction}

A significant part of the world's fruticulture is rainfed managed Olive, almond and vine are some of the perennial crops whose social and economic importance is huge throughout the Mediterranean basin and which mostly continue to be grown in rainfed conditions. Cover cropping is the most recommended soil management system in fruit growing. However, in rainfed managed orchards, soil tillage continues to dominate, and the use of herbicides is also widely used. In rainfed conditions there is a high risk of competition for water between herbaceous vegetation and trees, which makes difficult the widespread use of cover crops. However, there seem to be new clues to overcoming the problem, consisting of the use of less competitive plants, such as early-maturing self-reseeding annual legumes. These plants are able to protect the soil from erosion, sequester carbon and increase soil organic matter, fix nitrogen and promote the nutritional status of the trees and fruit yield. Their growing cycles finish early in spring which greatly reduces the competition for water.

\section{Soil management in fruit growing}

Soil tillage is the ancestral method of weed management in fruit growing. Soil tillage allowed the control of spontaneous vegetation when other methods of weed management on a large scale were not available. Currently soil tillage is still in use, with orchard floors being managed with cultivators, moldboard ploughs or disc harrows, once or twice during the spring and sometimes also in the fall. In certain situations, the orchards can be worked up to six times [1]. In spite of being an ancestral technique, tillage works, and the trees display a certain level of productivity. However, its merits started to be questioned, after several studies have highlighted its contribution to accelerating the process of soil erosion [2,3] and to enhance the mineralization of organic matter [4,5]. Furthermore, soil tillage carried out in the spring, close to flowering, may cause a severe stress in the trees in sensitive phases like flowering and fruit set, due to the destruction of the root system $[6,7]$. The damage to the root system reduces the yield potential of the tree due to the great demand of carbohydrates for the annual replacement of the rooting system.
The development of herbicide substances has created the opportunity of chemical weed control as an alternative or a complemental tool to soil tillage. In an initial phase, the use of residual or pre-emergence herbicides, those which prevent seed germination, was firstly widespread. Residual herbicides are usually applied from the autumn and repeated when needed, to obtain a bare soil throughout the year [8]. Sometimes residual active ingredients are associated with the same commercial product with post-emergence herbicides, those which kill growing plants, to obtain a most effective effect.

The use of herbicides may increase fruit production in comparison to tillage as it does not damage the root system, allowing it to explore the most fertile soil layer $[9,10]$. However, a permanent bare soil may favor soil erosion and lead to a progressive reduction of the soil organic matter in a similar way as occurs in soil tillage $[8,11]$. In the long term, vegetation becomes more difficult to control due to the increased herbicide resistance and changes in floristic composition, with vegetation being dominated by a high density of a few resistant species to the herbicides currently in use $[1,12]$.

In particular situations, herbicides can directly damage the trees and other non-target plants. Herbicides may also be associated with environmental hazard, especially in aquatic ecosystems $[13,14]$. Because of these problems, the use of residual herbicides has been progressively replaced by less harmful non-selective postemergence herbicides such as glyphosate. Using post-emergence herbicides, herbaceous vegetation can freely develop during the winter, protecting the soil from erosion and increasing soil organic matter, being destroyed only in spring when competition between herbaceous vegetation and trees become more severe [11]. In any case, the European Union is committed to reducing the use of pesticides in agriculture [15].

In recent years the focus on soil management in orchards has been on the introduction of cover cropping. Cover cropping is the most efficient way to reduce soil erosion $[2,16]$ and to increase 
soil organic matter [4,5], two key aspects in the sustainable management of the agro-systems. In humid climates and irrigated orchards, it is practically the only method of ground management currently in use. Usually the covers are managed with residual herbicides in the rows, to protect the trees and/or the irrigation system, and by mowing between rows $[17,18]$.

In rainfed managed orchards of arid and semi-arid environments the use of cover crops is not common. Herbaceous vegetation competes for water, which is the main limiting factor of tree crop growth and yield. It has been experimentally demonstrated that cover cropping reduces crop production, particularly if the orchard is kept in rainfed conditions $[9,10]$. Thus, most rainfed orchards continue to be tilled or maintained exclusively with herbicides, despite the potential benefits of cover crops in promoting soil fertility and the sustainability of agro-systems. Paradoxically, it would be the rainfed orchards that would most benefit from the protection afforded by cover crops, since they are installed in poorer fertility soils and steeper slops compared to irrigated orchards.

\section{Early-maturing pasture legumes for cover cropping in rain feed orchards}

Cover cropping may refer to spontaneous vegetation or seeded species. If the farmer decides to use seeded species, he believes that they will bring a benefit over the spontaneous vegetation, since they also have supplementary costs of installation and management. Among the several species or cultivars that can be used, there should be selected those known for bringing advantages and/or reducing hypothetical drawbacks. In rainfed orchards, in a semiarid environment, such as the Mediterranean basin, the species to be adopted should have one main feature: the growing cycle should be very short, to grow asynchronously with the trees and reduce competition for water. This is the only way to mitigate the impact of the covers on crop productivity. In addition, the covers should protect the soil during winter and increase its fertility. Installation and management should not be too expensive.

A particular group of plants may meet the requirements: self-reseeding early-maturing annual legumes. Early-maturing to reduce competition for water; self-reseeding to maximize soil protection in the fall and reduce costs by avoiding frequent sowing; and legumes to grow better on poor soils, sequester more carbon in the soil, fix atmospheric nitrogen and increase the biological activity of the soil [19].

Furthermore, cover cropping with sown legumes may also contribute to the increase of organic fruit farming. Organic farming has not been able to expand in fruit growing in the Mediterranean basin due to the lack of a natural source of nitrogen. In organic farming, industrial Haber-Bosch nitrogen fertilizers are not allowed, and commercial organic amendments authorized for organic farming are usually expensive to be used in amounts to meet plant needs [20].

However, legume cover crops may not be easy to manage. Several legume species with potential to be used as cover crops have been studied for a long time, their biology, ecology and agronomic behavior being sufficiently known, but only under pasture conditions. Thus, several new questions are raised when it is intended to use pasture legumes as cover crops in orchards. Is it possible to achieve persistence of these species without grazing? Will these species be maintained as soil fertility increases, in particular the availability of nitrogen, due to the competition of grasses? Is it possible to graze these covers without causing appreciable damage to orchard trees?

There seems to be a great deal of experimental work to be done in the near future. Although several studies have demonstrated the benefits of cover crops on erosion control and on the increase of organic matter and soil biological activity and biodiversity [21,22], the problem is the reduction in fruit yield, which usually occurs when the ground is managed with cover crops $[9,10]$, and from which depends the farmer's profit, one of the most determinant aspects of sustainability. Without profit the farmer does not maintain the activity. It is necessary to find models that meet both requirements, environmental benefits and good prospects of future and adequate short-term profitability. $[13,19]$ have demonstrated that cover cropping with early-maturing self-reseeding annual legumes in a rainfed managed olive orchard may fulfil all those objectives, including olive yield. Cover cropping increases plant nitrogen nutritional status and olive yield in comparison with a treatment of cover cropping with natural vegetation supplemented with $60 \mathrm{~kg} \mathrm{~N} \mathrm{ha}^{-1}$.

\section{Acknowledgment}

The authors are grateful to the Foundation for Science and Technology (FCT, Portugal) and FEDER under Programme PT2020 for financial support to CIMO (UID/AGR/00690/2013).

\section{Conflict of Interest}

No conflict of interest.

\section{References}

1. Zimdahl R (1993) Fundamentals of Weed Science. Academic Press, California, USA, pp. 758.

2. Keesstra S, Pereira P, Novara A, Brevik EC, Azorin Molina C, et al. (2016) Effects of soil management techniques on soil water erosion in apricot orchards. Sci Total Environ 551-552: 357-366.

3. Velarde FGA (2015) El cultivo de las plantaciones frutales. Ediciones Mundi-Prensa, Madrid.

4. Montanaro G, Celano G, Dichio B, Xiloyannis C (2010) Effects of soilprotecting agricultural practices on soil organic carbon and productivity in fruit tree orchards. Land Degrad Develop 21(2): 132-138.

5. Marquez Garcia F, Gonzalez Sanchez EJ, Castro Garcia S, Ordoñez Fernandez R (2013) Improvement of soil carbon sink by cover crops in olive orchards under semiarid conditions. Influence of the type of soil and weed. Spanish J Agric Res 11(2): 335-346.

6. Rodrigues MA, Cabanas JE (2009) Manutenção do solo. In: Rodrigues MA, Correia C (Eds.), Manual da Safra e contra Safra do Olival. Instituto Politécnico de Bragança, Portugal pp. 41-57.

7. Lisek J, Buler Z (2018) Growth and yield of plum trees in response to inrow orchard floor management. Turk J Agric For 42: 97-102.

8. Alcántara C, Soriano MA, Saavedra M, Gómez JA (2017) Sistemas de manejo del suelo. In: Barranco D, Fernández-Escobar R, Rallo L (Eds). El Cultivo del Olivo ( $7^{\text {th }}$ edn), Mundi-Prensa, Madrid, Spain, pp. 335-417.

9. Rodrigues MA, Lopes JI, Pavão FM, Cabanas JE, Arrobas M (2011) Effect of soil management on olive yield and nutritional status of trees in rainfed orchards. Commun Soil Sci Plant Anal 42(9): 993-2011. 
10. Ferreira IQ, Arrobas M, Claro AM, Rodrigues MA (2013) Soil management in rainfed olive orchards may result in conflicting effects on olive production and soil fertility. Spanish J Agric Res 11(2): 472-480.

11. Rodrigues MA, Arrobas M (2017) Manutenção do Solo. In: Rodrigues MA (Ed). Amendoeira: Estado da Produção. CNCFS, Bragança, Portugal, pp. 185-231.

12. Rodrigues MA, Dimande P, Pereira E, Ferreira IQ, Freitas S, et al. (2015a) Early-maturing annual legumes: an option for cover cropping in rainfed olive orchards. Nutr Cycl Agroecosyst 103:153-166.

13. Rodrigues MA, Cabanas JE, Lopes JI, Pavão F, Aguiar C, et al. (2009) Ground cover and dynamic of weeds after the introduction of herbicides as soil management system in a rainfed olive orchard. Rev Ciênc Agrár XXXII (2): 30-42.

14. Celis R, Trigo C, Facenda G, Hermosín MC, Cornejo J (2007) Selective modification of clay minerals for the adsorption of herbicides widely used in olive groves. J Agric Food Chem 55(16): 6650-6658

15. European Union (2009) Directive 2009/128/EC of the European Parliament and of the Council of 21 October 2009 establishing a framework for Community action to achieve the sustainable use of pesticides. Off J Eur Commun L 309: 71-86.

16. Torres MARR, Ordóñez Fernández R, Giráldez JV, Márquez García J Laguna A, et al. (2018) Efficiency of four different seeded plants and native vegetation as cover crops in the control of soil and carbon losses by water erosion in olive orchards. Land Degrad Dev 29(8): 2278-2290.

17. Sirrine JR, Letourneau DK, Shennan C, Sirrine D, Fouch R, et al. (2008) Impacts of groundcover management systems on yield, leaf nutrients, weeds, and arthropods of tart cherry in Michigan, USA. Agric Ecosyst Environ 125: 239-245.

18. Giese G, Velasco Cruz C, Roberts L, Heitman J, Wolf TK (2014) Complete vineyard floor cover crops favorably limit grapevine vegetative growth. Sci Hort 170: 256-266.

19. Rodrigues MA, Ferreira IQ, Freitas S, Pires J, Arrobas M (2015b) Selfreseeding annual legumes for cover cropping in rainfed managed olive orchards. Spanish J Agric Res 13(2): e0302.

20. Rodrigues MA, Pereira A, Cabanas JE, Dias L, Pires J, et al. (2006) Crops use-efficiency of nitrogen from manures permitted in organic farming. Eur J Agron 25(4): 328-335.

21. Montanaro G, Xiloyannis C, Nuzzo V, Dichio B (2017) Orchard management, soil organic carbon and ecosystem services in Mediterranean fruit tree crops. Sci Hort 217: 92-101.

22. Daryanto S, Fu B, Wang L, Jacinthe PA, Zhao W (2018) Quantitative synthesis on the ecosystem services of cover crops. Earth-Sci Rev 185: 357-373. 